\title{
CHEMICAL ETCHING OF ISOLATION GROOVES IN HIGH-POWER SILICON DEVICES
}

\author{
D. Šalucha ${ }^{a, b}$ and I. Šimkiené ${ }^{a}$ \\ ${ }^{a}$ Semiconductor Physics Institute, A. Goštauto 11, LT-01108 Vilnius, Lithuania \\ E-mail: irena@pfi.lt \\ b Joint Stock Company “Vilniaus Ventos Puslaidininkiai”, Ateities 10, LT-08303 Vilnius, Lithuania
}

Received 2 February 2009; revised 29 April 2009; accepted 18 June 2009

\begin{abstract}
The procedure of wet chemical etching, which plays an important role in the fabrication of high-power Si devices in standard commercial equipment, is discussed. The characteristics of isolation grooves in Si high-voltage thyristors and diodes have been investigated, with respect to etchants and wet etching conditions. It has been found that the standard deviation in the depth values of isolation grooves produced in the $\mathrm{Si}$ wafer of $125 \mathrm{~mm}$ in diameter is reduced to $0.85 \mu \mathrm{m}$ using a proposed modified technological procedure.
\end{abstract}

Keywords: wet chemical etching, silicon high-power devices

PACS: $61.82 . F k, 81.65 .-b, 85.30 . R s$

\section{Introduction}

Etching in acid or alkali solutions is one of the basic procedures in the fabrication of high-power Si devices. Silicon dissolves in fluoric acid and alkali solutions, whereas insoluble oxide film is formed on $\mathrm{Si}$ surface in reactions with other etching reagents. In the case of etchant composed of $\mathrm{HF}$ and $\mathrm{HNO}_{3}$, the solution of Si proceeds in several stages, each of which is followed by changes in chemical composition of both Si wafer and etchant [1]. The etching rate and surface morphology of Si are dependent on the concentration of acids and reaction product $\mathrm{H}_{2} \mathrm{SiF}_{6}$. Silicon acid $\mathrm{H}_{2} \mathrm{SiF}_{6}$ formed in the reaction is considered to be a strong acid comparable to sulfurous acid [2]. $\mathrm{H}_{2} \mathrm{SiF}_{6}$ is formed in a two-step process. In the first step, $\mathrm{Si}$ is oxidized by $\mathrm{HNO}_{3}$ resulting in formation of $\mathrm{SiO}_{2}$. In the second step, $\mathrm{Si}$ oxide $\mathrm{SiO}_{2}$ reacts with $\mathrm{HF}$, forming $\mathrm{SiF}_{4}$ that gives rise to $\mathrm{SiF}_{6}^{2-}$ by reacting with excess HF. The total reaction is [2]

$$
3 \mathrm{Si}+4 \mathrm{HNO}_{3}+18 \mathrm{HF} \rightarrow 3 \mathrm{H}_{2} \mathrm{SiF}_{6}+4 \mathrm{NO}+8 \mathrm{H}_{2} \mathrm{O} .
$$

Recent investigations have shown [3] that the etching mechanism of silicon is more complicated than that described by (1). Firstly, the oxidation of Si is caused by equilibrium reaction between nitric acid and nitrogen oxide [4]:

$$
2 \mathrm{HNO}_{3}+3 R a \rightarrow 3 R a \mathrm{O}+2 \mathrm{NO}+\mathrm{H}_{2} \mathrm{O},
$$

where $R a$ is a reducing agent. Secondly, nitrogen monoxide generates nitrous acid that is a dominant oxidizing reagent:

$$
\begin{aligned}
& \mathrm{H}^{+} \mathrm{NO}_{3}^{-}+2 \mathrm{NO}+\mathrm{H}_{2} \mathrm{O} \rightarrow 3 \mathrm{HNO}_{2}, \\
& 2 \mathrm{HNO}_{2}+R a \rightarrow R a \mathrm{O}+2 \mathrm{NO}+\mathrm{H}_{2} \mathrm{O} .
\end{aligned}
$$

In the absence of $\mathrm{HNO}_{2}$, the Si etching rate is very low [4] as the etching proceeds only due to reaction of $\mathrm{Si}$ with primary nitric acid. Therefore, in order to control the etching process, the reducing reagent should be used.

It is known that hydrogen and carbon are effective reducing elements. In etchants, acetic acid $\mathrm{CH}_{3} \mathrm{COOH}$ can be used as reducing reagent, which determines formation of $\mathrm{NO}$ and $\mathrm{HNO}_{2}$ and dilutes the concentrated acids. $\mathrm{CH}_{3} \mathrm{COOH}$ is a better solvent than water because of its permittivity (6.15) which is lower than that (81) of water. As a result, a lower dissociation and a higher oxidation degree of $\mathrm{HNO}_{3}$ are achieved during the etching process. In addition, a lower polarity of acetic acid, as compared to water, leads to a better wetting of a partially hydrophobic Si surface [5]. 
It should be noted that the formation of deep isolation grooves in $\mathrm{Si}$ wafer with $p-n$ junctions by wet etching differs from the etching process of a homogeneous substrate. During the etching process, hydrogen atoms penetrate into Si lattice, hence passivating $p$-type impurities like boron and resulting in a formation of a higher resistivity layer [6]. This process modifies the etching rate and the surface morphology of grooves, influencing simultaneously the breakdown voltage of high-power $\mathrm{Si}$ devices. Therefore, in order to improve the electrical parameters of Si devices, the chemical composition of etching solutions is to be carefully selected and the optimal etching conditions should be determined.

In conventional machining, the etching process and resulting quality of $\mathrm{Si}$ devices are also dependent on the stiffness of equipment and mechanical disturbances like vibrations and thermal deformations of the workpiece and machine [7]. Therefore, conventional machining properties should be optimized along with the control of wet etching process.

In this work the formation process of isolation grooves by wet etching procedure was analysed. The dependence of structural parameters of isolation grooves on the mechanism of etching procedure has been investigated in the fabrication process of thyristors and high-power Si diodes produced in "Vilniaus Ventos Puslaidininkiai". The chemical composition of acid etchants was optimized and the etching process was modified in order to improve the characteristics of fabricated devices. As a criterion of the effectiveness of the modified procedure, standard deviation of the depth of isolation grooves in Si wafers was considered.

\section{Investigated structures}

As substrates, $n$-type $\mathrm{Si}$ wafers of resistivity 60 $120 \Omega \mathrm{cm}$, diameter $125 \mathrm{~mm}$, thickness $0.37 \mathrm{~mm}$, and (111) crystallographic orientation were used. The $p-n$ junctions in the diode and thyristor structures have been formed by diffusion of boron and phosphorus for producing the $p$ - and $n$-type regions, respectively. The resulting carrier concentrations in $p$ - and $n$-type regions were $2 \cdot 10^{18}-1 \cdot 10^{14}$ and $6 \cdot 10^{13} \mathrm{~cm}^{-3}$, respectively. The arrays in wafers were separated by isolation grooves formed by wet chemical etching technique. Commonly, the grooves of $100 \mu \mathrm{m}$ in depth and $800 \mu \mathrm{m}$ in width were etched using $\mathrm{HF}: \mathrm{HNO}_{3}: \mathrm{CH}_{3} \mathrm{COOH}$ $[(3-1.7):(2-4):(0.7-2)(\mathrm{v} / \mathrm{v})]$ mixtures. In a further technological process, the grooves were filled with $\mathrm{SiO}_{2}-\mathrm{PbO}-\mathrm{Al}_{2} \mathrm{O}_{3}-\mathrm{B}_{2} \mathrm{O}_{3}$ compound which was melted into the glass by heating at $750-760{ }^{\circ} \mathrm{C}$.

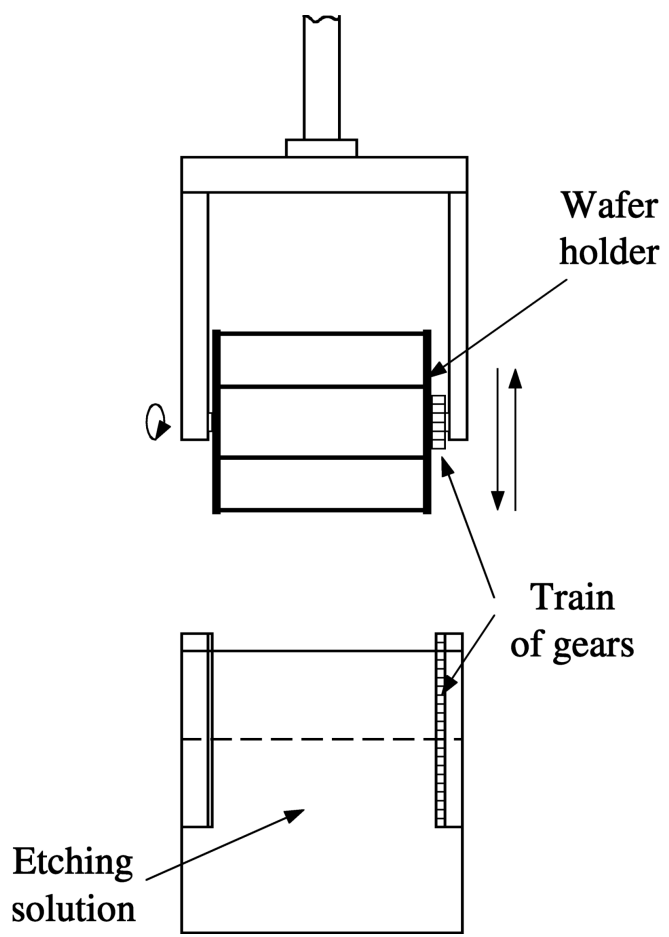

Fig. 1. A sketch of apparatus for etching the isolation grooves.

\section{Experiment}

In the fabrication of high-power $\mathrm{Si}$ devices, the industrial apparatus installed in "Vilniaus Ventos Puslaidininkiai" was used. The sketch of wet-etching equipment is presented in Fig. 1. The etching cell with 25 wafers was immersed in etching solution. The cell was moving up and down and rotated along the horizontal axis by means of the train of gears. The temperature during the etching process was controlled.

The depth of the grooves was measured making use of a contact stylus of DekTak 6M profilometer (Veeco). The numerical results presented in this work are based on the experimental data obtained in 655 runs of the measurements of isolation grooves in $131 \mathrm{Si}$ wafers. The depth $d$ of isolation grooves was measured at 5 points in each wafer. The average depth $\bar{d}$, depth range $R=d_{\max }-d_{\min }$, where $d_{\max }$ and $d_{\min }$ are maximum and minimum values of depth, respectively, and standard deviation $s_{d}=\sqrt{\left[\Sigma\left(d_{i}-\bar{d}\right)^{2}\right] /(i-1)}(i=5)$ were calculated for each $\mathrm{Si}$ wafer.

\section{Results and discussion}

In order to improve the characteristics of fabricated high-power Si devices, the main attention was paid to the etching process. In processing of high-power $\mathrm{Si}$ devices, the quality of etching is characterized by the range $R$ of the depth values and the profile of isolation 


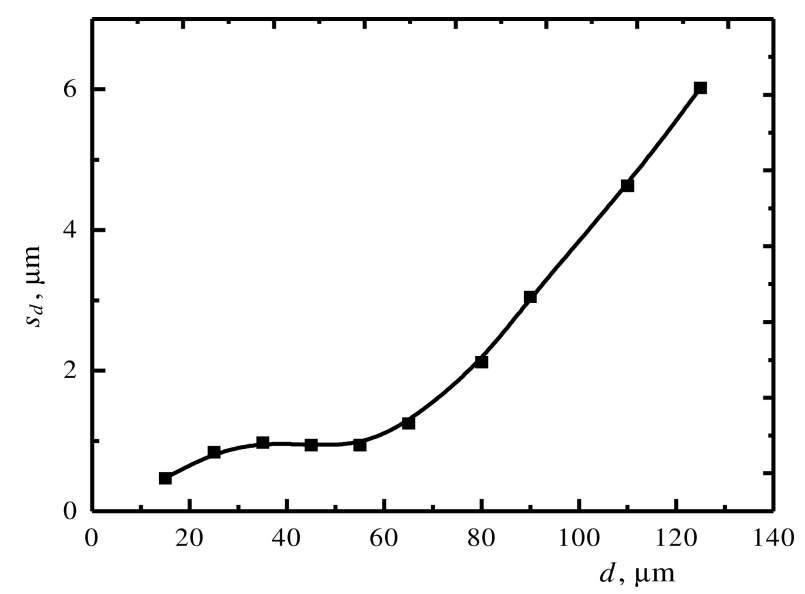

Fig. 2. Dependence of values of the standard deviation in depth on the depth of isolation grooves formed by wet-etching technique. Etching cell rotated at a speed of $38 \mathrm{rpm}$. The curve is a guide to an eye.

grooves in wafer. The $R$ values determine mechanical characteristics of wafer, such as hardness, which are important in further technological procedure.

Experimental data showed that $R$ values as well as standard deviation $s_{d}$ (Fig. 2) increased with increasing $d$ values. The $s_{d}$ values presented in Fig. 2 were determined for isolation grooves formed on $\mathrm{Si}$ wafers etched at a standard speed of $38 \mathrm{rpm}$. As seen from Fig. 2, the depth-dependence of $s_{d}$ is a non-monotonous function with a particular point at $d \sim 70 \mu \mathrm{m}$ corresponding to the location of the $p-n$ junction. The $s_{d}$ values are almost independent on depth in the $p$-type region whereas a steep increase is noticed in the $n$-type region. This observation is in agreement with the etching rate for $p$ - and $n$-type $\mathrm{Si}[6]$. A low etching rate in $p$-type $\mathrm{Si}$ has led to low values of $R$ and $s_{d}$, whereas in the $n$-type region at larger $d$ values a higher etching rate caused an increase of $s_{d}$ values.

The observed regularities are well understood after a more detailed analysis of the etching process. As described above, the formation of silicon acid $\mathrm{H}_{2} \mathrm{SiF}_{6}$ occurs in two steps [8]:

$$
\begin{aligned}
& 3 \mathrm{Si}+4 \mathrm{HNO}_{3} \rightarrow 3 \mathrm{SiO}_{2}+4 \mathrm{NO}+2 \mathrm{H}_{2} \mathrm{O}, \\
& \mathrm{SiO}_{2}+6 \mathrm{HF} \rightarrow \mathrm{H}_{2} \mathrm{SiF}_{6}+2 \mathrm{H}_{2} \mathrm{O} .
\end{aligned}
$$

However, in these reactions the crucial and yet unresolved step is oxidation of $\mathrm{Si}$ by nitric acid. On the one hand, recent studies have shown [8] that during the etching in acid mixtures, the injection of holes into semiconductor valence band occurs due to reduction of nitric acid on $\mathrm{Si}$ surface. This process indicates the electrochemical origin of the reaction. In $\mathrm{HF}-\mathrm{HNO}_{3}$ mixtures the electrochemical origin of etching process is confirmed by the formation of porous $\mathrm{Si}$ layers [9]. On the other hand, the presence of several combined equilibria between different nitrogen oxides was proposed [5] to lead to the formation of nitrous acid as a reactive species in the etching process (3), (4). Indeed, the best morphology of Si surface was obtained in $\mathrm{HNO}_{3}$-rich $\mathrm{HF} / \mathrm{HNO}_{3} / \mathrm{CH}_{3} \mathrm{COOH}$ solutions, in an apparent agreement with this mechanism [5]. However, this mechanism does not explain how nitric acid is reduced on $\mathrm{Si}$ (111) surface passivated by hydrogen [10].

On the basis of considerations presented above, it is reasonable to assume that (i) nitric acid, as oxidizing agent, generates two holes and oxidizes the surface $\mathrm{Si}$ atoms to $\mathrm{Si}^{2+}$ according to chemical reaction and (ii) fluoric atoms replace hydrogen atoms on $\mathrm{H}$ passivated Si surface in accordance with electrochemical mechanism [11].

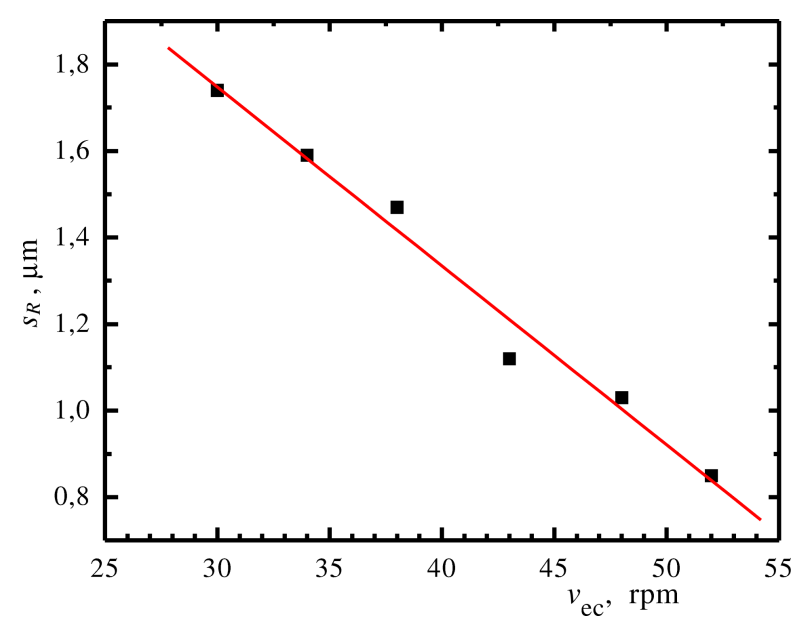

Fig. 3. Dependence of the standard deviation of the depth range $s_{R}$ on the rotation rate of etching cell $v_{\mathrm{ec}}$ at a constant depth $d=$ $100 \mu \mathrm{m}$ of isolation grooves.

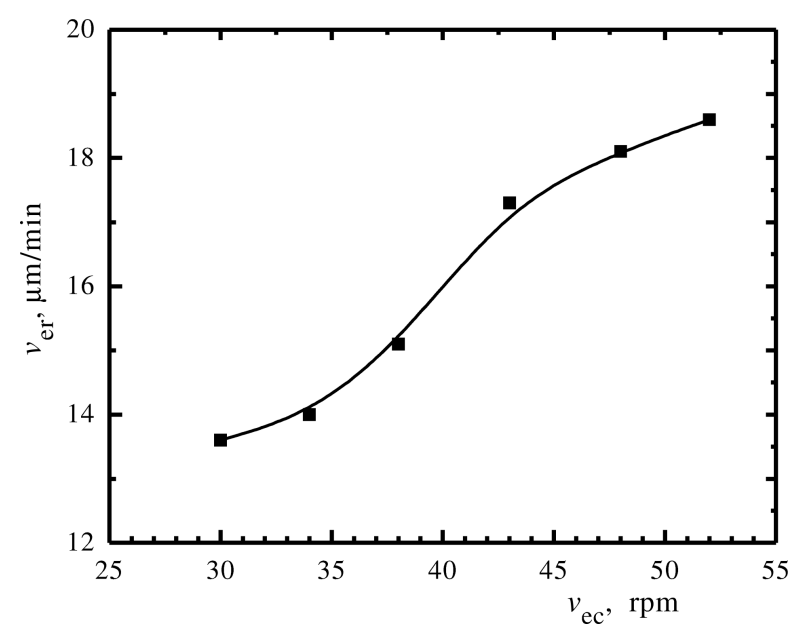

Fig. 4. Dependence of etching rate $v_{\text {er }}$ on the rotation speed $v_{\text {ec }}$ of etching cell at a constant depth $d=100 \mu \mathrm{m}$ of isolation grooves. The curve is a guide to an eye. 
As noted above (see Fig. 2), experimental data have shown that standard deviation of the depth of isolation grooves is almost constant in the $p$-type $\mathrm{Si}$ region indicating a low etching rate. However, the etching rate is strongly dependent on carrier concentration [12] which varies by four orders of magnitude in the $p$-type region of high-power Si devices under consideration [13]. It is reasonable to assume that hydrogen atoms, which have originated as the reaction products, penetrate into Si during etching process and passivate dopant boron atoms leading to a formation of a high-resistivity layer. As a result, the etching rate is low, leading to low $s_{d}$ values of the depth of isolation grooves. An increase of $s_{d}$ values in the $n$-type region can be explained by increased etching rate due to the absence of hydrogen passivation effect.

In order to decrease the range of $d$ values over the wafer, the dependence of standard deviation $s_{R}$ (the standard deviation of the depth range) on the rotation speed of etching cell $v_{\mathrm{ec}}$ was examined. For this purpose, the mechanism of train gears in the etching cell was improved to increase the rotation speed of the etching cell. However, the rotation speed was limited to $v_{\mathrm{ec}}<60 \mathrm{rpm}$ because of the construction of apparatus.

Experimental data have shown (Fig. 3) that the isolation grooves are more uniform in depth at higher $v_{\mathrm{ec}}$ values. Therefore, it was proposed to increase the rotation speed of the etching cell up to $52 \mathrm{rpm}$. The increase of $v_{\mathrm{ec}}$ from 30 to $52 \mathrm{rpm}$ resulted in the decrease of standard deviation of the depth range $s_{R}$ from 1.74 to $0.85 \mu \mathrm{m}$.

The increase of rotation speed $v_{\mathrm{ec}}$ of etching cell resulted in the increase of etching rate, too (Fig. 4). For example, the etching rate was increased from 13.6 to

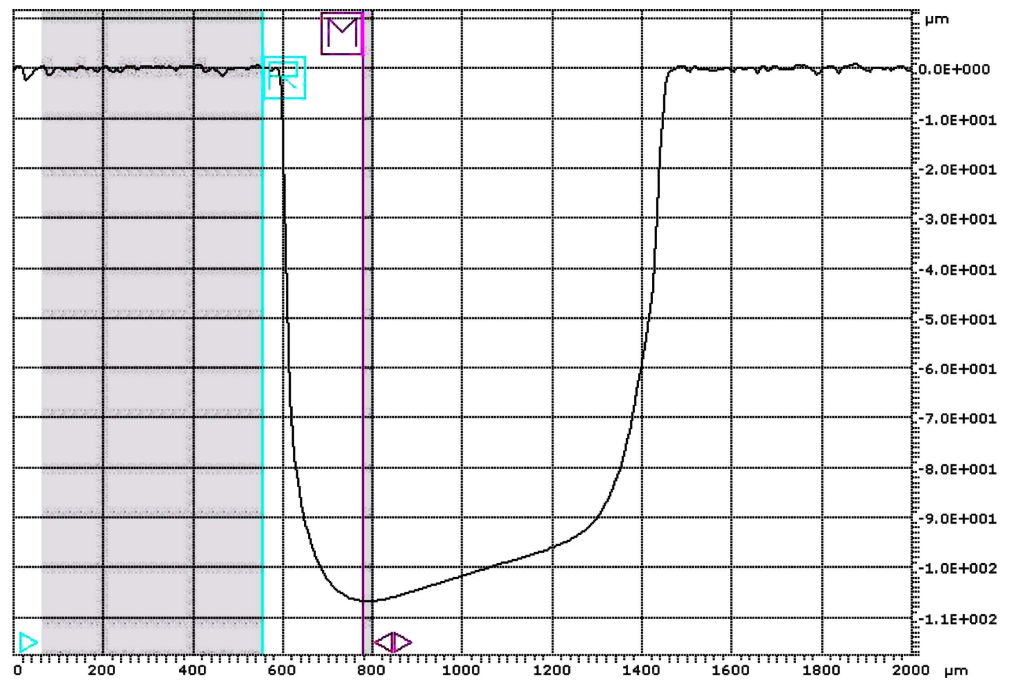

(a)

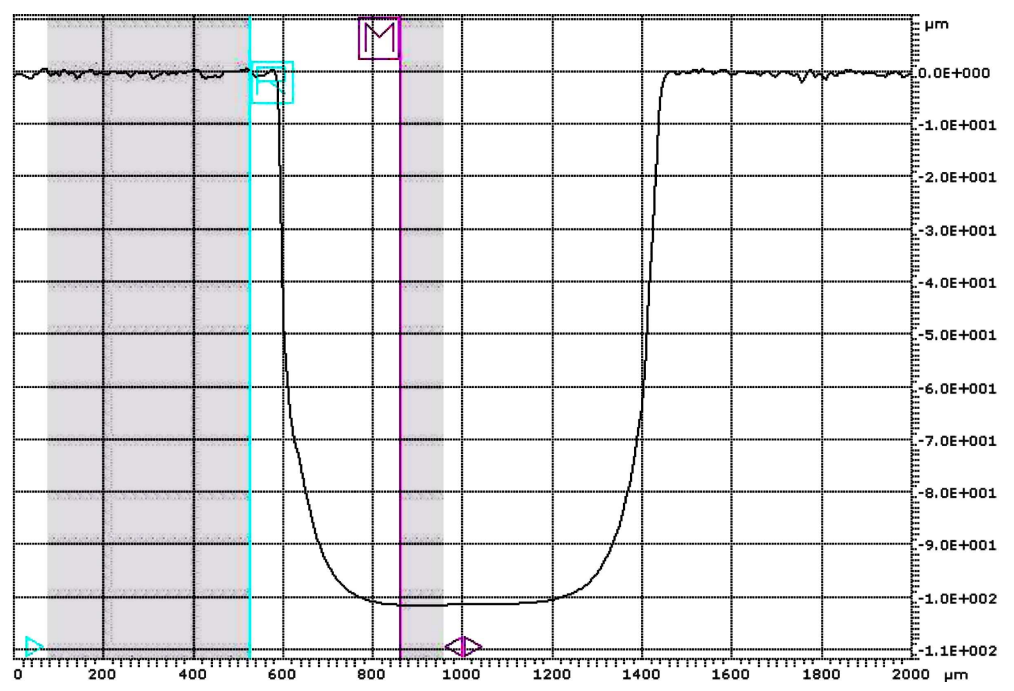

(b)

Fig. 5. Profile of the isolation grooves formed at the rotation of the etching cell with a speed of (a) $30 \mathrm{rpm}$ and (b) $52 \mathrm{rpm}$. 
$18.6 \mu \mathrm{m} / \mathrm{min}$ at the increase of rotation speed from 30 to $52 \mathrm{rpm}$. This dependence is caused by the enhanced homogeneity of the etchant and a more efficient removal of reaction agents at the local wet etching process. As a result, the etching rate was increased and it was more homogeneous over the wafer.

The increase of $v_{\mathrm{ec}}$ has also resulted in the improvement of the profile of isolation grooves. As seen from Fig. 5, the bottom of the isolation groove is smoother at higher rotation speed of the etching cell. The improvement of morphology is mainly due to an easier removal of the reaction products.

\section{Summary}

The formation of isolation grooves by wet chemical etching has been investigated in the case of high-power Si devices produced by means of industrial etching apparatus in order to improve the efficiency of this step in the technological procedure. Two problems in the etching process have been discussed. The first problem was related to the chemical composition of the etching solution. It has been shown that using the $\mathrm{HNO}_{3}$-rich $\mathrm{HF} / \mathrm{HNO}_{3} / \mathrm{CH}_{3} \mathrm{COOH}$ etchant for $\mathrm{Si}(111)$, the combined electrochemical and chemical reaction under hydrogen evolution is dominant. As a result, the etching rate is weakly dependent on the doping rate in $p$-type Si. The second problem under consideration was the etching rate and removal of reaction products from the forming isolation grooves. The standard deviation in the depth of isolation grooves was determined to decrease with the increase of rotation speed of the etching cell due to a more efficient removal of the reaction products. As a result, the profile of the isolation grooves was smoother at a higher rotation rate.

Studies of the etching process in fabrication of highpower $\mathrm{Si}$ devices have given a new insight into reaction mechanism of isotropic acidic etching of Si. An improvement of technology has led to lower values of standard deviation for the depth and smoother profile of isolation grooves in $\mathrm{Si}$ substrates.

\section{References}

[1] M. Steinert, J. Acker, M. Krause, S. Oswald, and K. Wetzig, Reactive species generated during wet chemical etching of silicon in $\mathrm{HF} / \mathrm{HNO}_{3}$ mixtures, J. Phys. Chem. B 110, 11377-11382 (2006).

[2] A. Henßge, J. Acker, and C. Müller, Titrimetric determination of silicon dissolved in concentrated HF$\mathrm{HNO}_{3}$-etching solutions, Talanta 68, 581-585 (2006).

[3] J. Acker and A. Henßge, Chemical analysis of acidic silicon etch solutions: II. Determination of $\mathrm{HNO}_{3}, \mathrm{HF}$, and $\mathrm{H}_{2} \mathrm{SiF}_{6}$ by ion chromatography, Talanta 72,1540 1545 (2007).

[4] A. Oltersdorf, M. Zimmer, M. Seitz, and J. Rentsch, Analytical research of the acid etching bath by ion chromatography, in: Proceedings of the 23rd European Photovoltaic Solar Energy Conference and Exhibition, 1-5 September, Valencia, Spain (2008), www.ise.fraunhofer.de .

[5] M. Steinert, J. Acker, A. Henßge, and K. Wetzig, Experimental studies on the mechanism of wet chemical etching of silicon in $\mathrm{HF} / \mathrm{HNO}_{3}$ mixtures, J. Electrochem. Soc. 152, C843-C850 (2005).

[6] J. Weber, S. Knack, O.V. Feklisova, N.A. Yarkin, and E.B. Yakimov, Hydrogen penetration into silicon during wet-chemical etching, Microelectron. Eng. 66, 320-326 (2003).

[7] K. Yamamura and T. Mitani, Etching characteristics of local wet etching of silicon in $\mathrm{HF} / \mathrm{HNO}_{3}$ mixtures, Surf. Interf. Anal. 40, 1011-1013 (2008).

[8] M. Steinert, J. Acker, S. Oswald, and K. Wetzig, Study on mechanism of silicon etching in $\mathrm{HNO}_{3}$-rich $\mathrm{HF} / \mathrm{HNO}_{3}$ mixtures, J. Phys. Chem. C 111, 2133-2140 (2007).

[9] D. Šalucha, I. Šimkiene, and J. Sabaityte, Formation of nanostructured layers for passivation of high power silicon devices, Acta Phys. Pol. A 113, 1079-1083 (2008).

[10] M. Ramonda, Ph. Dumas, and F. Salvan, On the rougness of perfectly flat $\mathrm{H}-\mathrm{Si}(111)$ surfaces an atomic force microscopy approach, Surf. Sci. 411, L839-L843 (1998).

[11] V. Lehmann, The chemical dissolution of silicon, in: The Electrochemistry of Silicon: Instrumentation, Science, Materials and Applications (Wiley-VCH, Weinheim, Germany, 2002) p. 23.

[12] M.J. Madou, Fundamentals of Microfabrication, 2nd ed. (CRC Press, Boca Raton, FL, 2002) p. 209.

[13] E.S. Kooij, K. Butter, and J.J. Kelly, Silicon etching in $\mathrm{HF} / \mathrm{HNO}_{3}$ solution: Charge balance for the oxidation reaction, Electrochem. Solid-State Lett. 2, 178180 (1999). 


\title{
DIDELĖS GALIOS SILICIO PRIETAISŲ IZOLIAVIMO GRIOVELIŲ CHEMINIS ĖSDINIMAS
}

\author{
D. Šalucha ${ }^{\mathrm{a}, \mathrm{b}}$, I. Šimkiené ${ }^{\mathrm{a}}$ \\ ${ }^{a}$ Puslaidininkiu fizikos institutas, Vilnius, Lietuva \\ ${ }^{\mathrm{b}}$ Akcine bendrove „Vilniaus Ventos puslaidininkiai“, Vilnius, Lietuva
}

\section{Santrauka}

Nagrinejjamas izoliacinio griovelio gylių verčiu kitimo intervalo ir jų standartinio nuokrypio mažinimo metodas didelès galios silicio prietaisuose. Nustatyta, kad gilejjant izoliaciniams grioveliams kartu auga standartinis nuokrypis. Izoliacinio griovelio gy- lių verčių standartinis nuokrypis sumažintas nuo 1,74 iki $0,85 \mu \mathrm{m}$, didinant èsdinimo kasetės sukimosi greiti èsdiklyje nuo 30 iki 52 aps/min. Nustatyta, kad kartu pakito ir èsdinimo greitis nuo 13,6 iki $18,6 \mu \mathrm{m} / \mathrm{min}$. Ištirta èsdinimo kasetès sukimosi greičio itaka izoliacinio griovelio dugno formai ir morfologijai. 